\title{
Open Science and the emergence of preprints
}

\author{
Dagmar Elaine Kaiser ${ }^{\mathrm{a}}$ \\ Maria da Graça Oliveira Crossetti ${ }^{b}$
}

\section{How to cite this article:} Kaiser DE, Crossetti MGO. Open Science and the emergence of preprints [editorial]. Rev Gaúcha Enferm. 2021;42:e20210030 doi: https://doi.org/10.1590/19831447.2021.20210030
Universidade Federal do Rio Grande do Sul (UFRGS), Escola de Enfermagem, Departamento de Assistência e Orientação Profissional. Porto Alegre, Rio Grande do Sul, Brasil.

- Universidade Federal do Rio Grande do Su (UFRGS), Escola de Enfermagem, Departamento de Enfermagem Médico-Cirúrgica. Porto Alegre, Rio Grande do Sul, Brasil.
In the context of this journal, Revista Gaúcha de Enfermagem, the debate on the particularities regarding the new preprint model of publication has been a present topic and has stimulated intense debate in the scientific communication and editorial communities considering the contradictions that surround this model. At the same time, the editors have been consulted regarding the priority action lines of SciELO, the Scientific Electronic Library Online, in order to consolidate their own preprint repository, according to the international scientific publication trends towards Open Science, which has been integrating more and more the debate in forums and specific events ${ }^{(1-2)}$.

Researchers of the National Institutes of Health and the Whitehead Institute define preprint submission as 'a complete written description of a body of scientific work that has yet to be published in a journal'(3). In other words, a preprint can be a research article, editorial, review or other text that is ready to be submitted to a journal for peer review or is under review, or even that has been rejected, but the authors are willing to make the content public, no matter what the study result was. Besides, since it does not go through a process of peer review or has not been accepted for print, it becomes a fast, freely distributed in open repositories, reproducible and reusable communication — specially because the authors can simultaneously submit the same preprint document to a peer-review journal (2).

The complexity of the debate appears in the movement for Open Science and the polemics that involve the adoption of the preprint, which implies from changes in the publication process to the clash with commercial publishers ${ }^{(2)}$, since open access to research in preprint servers brings new meaning and possibilities to the publicization of public and social interest studies: something that is under discussion and evaluation by scientific journals.

The preprint is reaching Brazil in fields such as Nursing and Health Sciences. This was to be expected, considering the history of this distribution form in fields as different as Physics and Computing Sciences, especially in the United States, where there are several consolidated preprints repositories. Preprints are being seen as an important step towards free and universal access to the knowledge produced by scientists worldwide that needs to be published (2). In Brazil, the demand for more rapid publication of research results, particularly in terms of public health, started with the acceptance of preprints at Oswaldo Cruz Institute's journal Memórias.

In the scope of the publications of the blog SciELO in Perspective, this new form of social production, distribution and appropriation of information and knowledge in science, 
technology and innovation of preprints is represented in the strategy of Plan $\mathrm{U}$, a tactic for universal access to productive and low-cost research to provide researcher's open access to the results of research ${ }^{(5)}$. Thus, besides open scientific data sharing, agility in the socialization of results, open scientific tools, open laboratory notebooks, discoveries or research selections ${ }^{(2,6)}$, the preprint model gives priority to discoveries and ideas, is low cost and easily found, accessed and cited, since it does not undergo the typical flow of a peer-review publication ${ }^{(5)}$. It also enhances career progression and improves communication culture in the scientific community ${ }^{(7)}$.

In fact, this movement for Open Science bring the benefits that come from the adoption of the preprint model: agility, considering the rapid availability online of the document to the scientific community for reading and citation ${ }^{\left({ }^{8}\right)}$; free, unrestricted and open access ${ }^{(5)}$; assurance of originality, ensuring the priority of the discovery or research topic to the author, institution, laboratory of research group ${ }^{(8)}$. The adoption of the preprint model also straightly relates to the defense of Open Science when it makes research results freely available for authors and readers in a free online repository that favors authors with the exemption of submission and publication rates or even of the fees for accessing the published articles, generating economies. Besides, other advantages are the increasing number of publications, considering that the distribution of preprints uses DOI (Digital Object Identifier) (2); the improvement of the manuscript, since the preprint can be commented by peers and improved in future versions, which can be accessed by readers ${ }^{(5)}$; simultaneous submission, since a preprint submission does not prevent that the manuscript be submitted to a peer-review journal ${ }^{(8)}$. Furthermore, the minimization of study duplication has been mentioned, since the fast availability of research results can prevent financial investment in new studies, because there are already trials in course ${ }^{(2)}$. Other aspects highlighted in literature were the publication of negative results in the preprint model, often rejected by peer-review journals, and the assurance of publication, because even if it takes time for the manuscript to be evaluated by a journal or to be rejected, it will be distributed through preprint ${ }^{(8)}$. As the preprints can present methodological, statistic and other mistakes, agility in publication can allow for easy detection of these mistakes and correction for future versions ${ }^{(2)}$. Another point to highlight is the fast dissemination of the manuscript, which increases the preprints' citation window ${ }^{(8)}$.

As we reinforce the many benefits of adopting the preprint publication model and the steps towards the alignment to Open Science practices, some challenges to its implementation should be defined in the fields of Nursing and Health Sciences: partial information from the production of knowledge can have an impact on professional practice, as well as an impact on people's and collective health. Therefore, a preprint demands quality and an important theoretical discussion of potentials and limits previously to the adoption of the tactic model.

\section{REFERENCES}

1. Spinak E. 0 que é este tema dos preprints? 2016 nov 22 [citado 2021 fev 02] In: SciEL0 em Perspectiva [Internet]. São Paulo: SciEL0; c2016-. [aprox 1 tela]. Disponível em: https://blog.scielo.org/blog/2016/11/22/0-que-e-este-tema-dos-preprints/

2. Souza JRS. The emergence of preprints for Brazilian science: considerations from the Nursing area. Rev Esc Enferm USP. 2019;53:e03534. doi: https://doi.org/10.1590/ S1980-220X2019020803534

3. Bourne PE, Polka JK, Vale RD, Kiley R. Ten simple rules to consider regarding preprint submission. PLoS Comput Biol. 2017;13(5):e1005473. doi: https://doi.org/10.1371/ journal.pcbi.1005473

4. Pirmez C. Na rota da ciência aberta as Memórias do Instituto Oswaldo Cruz aceitam submissão de manuscritos preprints. 2017 dez 07 [citado 2021 fev 02]. In: SciELO em Perspectiva [Internet]. São Paulo: SciELO; c2017- . [aprox. 1 tela]. Disponível em: https://blog.scielo.org/blog/2017/12/07/ na-rota-da-ciencia-aberta-asmemorias-do-instituto-oswaldo-cruz-aceitam-submissao-de-manuscritos-preprints/

5. Spinak E. 0 que é o Plano U: acesso universal à pesquisa científica via preprints? 2019 jun 19 [citado 2021 fev 02]. In: SciEL0 em Perspectiva [Internet]. São Paulo: SciEL0; c2019- [aprox 1 tela]. Disponível em: https://blog.scielo.org/blog/2019/06/19/0-que-e-0-plano-u-acesso-universal-a-pesquisa-cientifica-viapreprints/

6. Albagli, Sarita. Ciência aberta como instrumento de democratização do saber. Trab Educ Saúde. 2017;15(3):659-60. Disponível em: https://doi. org/10.1590/1981-7746-sol00093.

7. Packer AL, Santos S, Meneghini R. SciELO Preprints a caminho. 2017 fev 22 [citado 2021 fev 02]. In: SciELO em Perspectiva [Internet]. São Paulo: SciEL0; c2017- . [aprox. 1 tela]. Disponível em: https://blog.scielo.org/blog/2017/02/22/scielo-preprints-a-caminho/

8. Barbosa DA, Padilha MI. Ethical dilemmas for the areas of nursing and health in relation to preprints. Rev Bras Enferm. 2018;71(Suppl 6):2602-3. doi: https://doi. org/10.1590/0034-7167.201871sup|601

\section{- Corresponding author:}

Maria da Graça Oliveira Crossetti

E-mail:mgcrossetti@gmail.com 